\title{
CDCA7 Gene
}

National Cancer Institute

\section{Source}

National Cancer Institute. CDCA7 Gene. NCI Thesaurus. Code C152968.

This gene is involved in MYC-dependent cell proliferation. 